\title{
ONLINE COMMUNITY FOR ENHANCING WOMEN PARTICIPATION IN POLITICS AND DECISION MAKING CASE STUDY TANZANIA
}

\author{
ジセラ·モボイエ ${ }^{1}$, 山中俊之 ${ }^{*}$
}

\section{Gisela MBOYE$^{1}$, Toshiyuki YAMANAKA ${ }^{1 *}$}

1. 神戸情報大学院大学

Graduate School of Information Technology

Kobe Institute of Computing

广 $650-0001$ 神戸市中央区加納町 2-2-7

\begin{abstract}
Women participation and representation in key positions, governance, and decision making organs lower than that of men despite a high number in the population. They do not have enough seats in local governments, parliamentary houses, judiciary, and the executive houses as well. The proposed solution is Online community application named Wanawake Tujijenge. The system is intended to be used by any woman in Tanzania by creating ways in organizing women network in politics. As a platform for communication among women they can discuss political matters, share knowledge, skills in leadership, raise awareness of women political activism and promote positive norms regarding women's equal participation and representation in leadership. The system was tested and verified by several users in Tanzania and usability satisfaction is $75 \%$
\end{abstract}

女性の主要ポジションや意思決定における参画は男性に比べ遅れている。女性は政府、議会、司 法、エグゼクティブにおいて十分な席を持っていない。オンラインコミュニティである Wanawake Tujijenge によって、女性の政治的ネットワークの仕組みを作った。コミュニケーションを取り、議論し、 知識を共有して、リーダーシップスキルを習得して、意識を高める。この仕組みはタンザニアのユー ザーに活用されて $75 \%$ の満足度を得ることができた。

Keywords: women political participaton, decision-making, quota system ,online community, mass media, information communication technology, MPs=member of parliament

キーワード = 女性の政治参画、意思決定、クオータシステム、オンラインコミュニティ、マスメディア、情報コミュ ニケーションシステム、国会議員

\section{Introduction}

\subsection{Current situation}

In 1961, Tanganyika got its independent. In 1962, it became a one-party state and later on adopted multi-party democracy in 1992. There are two levels of Tanzania government which are central and local government. United Republic of Tanzania Constitution Article 21 emphasizes equal participation of citizens in the governance of the country either directly or indirectly through representative democracy. However, the inequality between men and women in decision making machineries continues despite this constitutional provision. To address the gender imbalance, quota system was adopted. According to the Tanzania constitution amendments in 1977 stipulates that women 
should consist of at least 30 percent of the parliament. The special seats for women in the National Assembly are determined by the total percentage of parliamentary votes collected by each party at the polls. These reserved seats for women are then distributed among the political parties in proportion to the total number of votes they received as a party. In order to qualify to offer a special seat candidate, the political party must have at least five percent of the total parliamentary votes.

\subsection{Problem statement}

However, obstacles remain to full gender equality in government, and some challenges are a direct result of the quota system in which women are either directly elected or are nominated for the special quota seats. One challenge is the very small portion of directly elected MP who are women. Example in 2010, there were 125 women altogether of a total 339 MPs, and only 20 of these were elected from the constituencies, (IPU, 2015). Also, there are other obstacles facing women seeking political office including;

- Women have lack of confidence and skills on political-campaign

- Family work and unofficial timetable. women spend more time in domestic activities such as taking care of children and cooking which make them difficult to engage in politics

- Less Access of important information Women have been a disadvantaged group to lack most of the important information like when and where political meetings happen

\subsection{The role of ICT (mass media)}

In Tanzania, there are several mass media such as radios, newspapers, televisions and magazines that support for women's political participation where they raise their view together and communicate their standpoint in different matters to decision makers and different stakeholders all levels of government.
Tanzania Media Women's Association (TAMWA) holds radio and television programs that promote the engaging of women in politics. TAMWA is offering training of members so that they can improve their skills, empowering women with different skills so that they can analyze gender, political, social and cultural issues for the purposes of effecting positive change in the country. It also publishes its own named magazine (Voice of Siti) which comes out few times. It has also published several leaflets, pamphlets, posters and booklets on the same contents.

According to IRI (2016) While some improvements have been made, largely due to the efforts of organizations such as TAMWA, there still no equal coverage of men and women in election-related news stories. Representatives from these organizations and media monitoring reports from Gender Links and other media groups, this seems to be true in several areas: 1) women are cited as sources on election-relation news less frequently than men; 2) women candidates receive less media coverage than male candidates; and 3) when women candidates do receive coverage, gender stereotypes often characterize the stories

Generally, women are getting harder competing with men in any type of political election, therefore it is critically important for them to be aware of the importance of building a strategic partnership with digital platforms

\section{DATACOLLECTION TECHNIQUES}

\subsection{Qualitative method}

There are various secondary sources mainly from journal article, government and nongovernment organization report, book and others. Secondary research is research based on secondary resources that already exist. This method made it possible for the researchers to explore challenges and opportunities of women political participation in Tanzania and whole the world.

\subsection{Questionnaires}


Questionnaires used as a method for collecting data for this research in Tanzania. Based on questionnaires were designed using google forms and they were formulated based on the research questions. Google forms were chosen because they were the most convenient way to gather information from women group from Tanzania via email without sending them physically.

\subsection{Observation Method}



The researcher applied Observation as another method of data collection technique for her research. I have been observing since I grew in my home place Tanzania where I witnessed that more than $80 \%$ of the local government leadership position such as village chairperson and ward councilors were under men. From there I can understand how women who are willing to become a leader and with their obstacles they have been faced.

\section{SYSTEM DESIGN IMPLEMENTATION}

\subsection{Preliminary questionnaire results}

Before developing its solution, the researcher established a number of questions for the targeted people (women from Tanzania) as the users regarding the use of online platform as a tool to share ideas and useful discussion about politics. As shown in the figure 1, 86.2\% of responses believe that the online platform will help to impact knowledge to most of the women. Based on that questionnaire, the author starts designing the prototype.

Figure 1: Responses from the users

\subsection{Prototype overview}

The proposed system is online community application titled as WanawakeTujijenge. The system creates opportunities for sharing experiences skills and good practices between women in politics, activists, practitioners, academics, and policymakers engaged in promoting women's political participation fosters exchange, dialogue(discussion) and knowledge creation for all who are engaged in promoting women's political participation. Also provide excellent opportunities to link women leaders and visionaries from different places without worrying about the cost, time or geographical barrier. Within the platform they acquire daily news, programs, and different publications. Figure 2 shows the architectural layout of the system. Both the administrator and the user access the system through internet. With growth of technology the system will be responsive and adaptive.

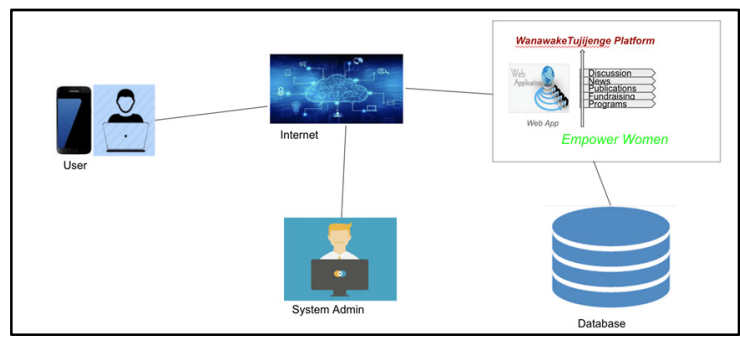

Figure 2: System Architecture

\subsection{Use case diagram}

To illustrate how the system proposed work, Unified Modeling Language (UML) was used to provide system frameworks and easy understanding of the system. WanawakeTujijenge was implemented by using PHP web programming language, HTML, CSS, JavaScript as well as MYSQL database. The App has two actors of the system with a different way of interacting with the system (see fig 3). The administrator has a privileged role to 
access the system, can manage and register the users, also as a subscriber, editor, and author.

\section{And normal}

user act as a subscriber and contributor.

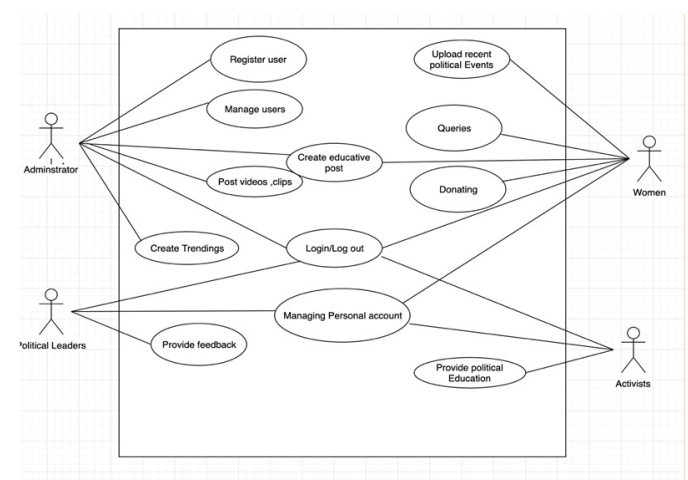

Figure 3: Use case diagram

\subsection{System Implementation}

The development the web based WanawakeTujijenge platform, the screen layout was one of the significant considerations. To make sure that the users will get motivated and impressed and not get discouraged and disuse the system as soon as they accessed the website, the interface had to be well designed and yet simple. Therefore, for each screen the following were considered. That is, the contents of a screen, page navigation, and how the information would be presented. Below are screen shots for home page

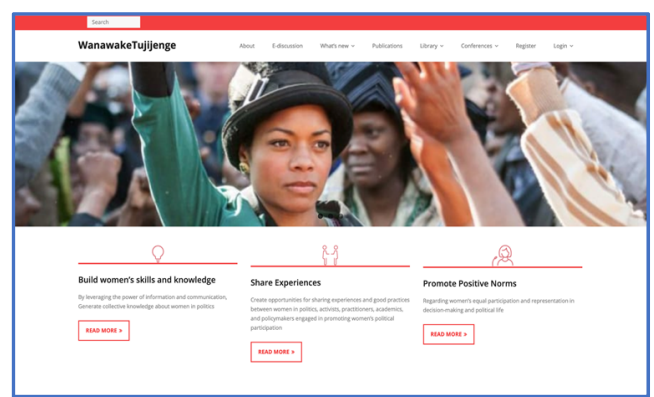

Figure 4: Screen shot WanawakeTujijenge platform Homepage

\section{Testing and Verification}

The proposed solution was tested and verified by several users, about 10 students from Kobe institute of Computing and 20 women from
Tanzania. The verification helps the researcher to evaluate the effectiveness and efficiency of the system.

\subsection{Information importance}

The respondents were asked whether the information provided on the platform was helpful for to improve skills and knowledge on leadership. Out of the 30 respondents (70\%) agreed the information was helpful

\subsection{Application satisfaction}

The respondents required to indicate the usability satisfaction with the application. About (60\%) respondents were very satisfied, $(20 \%)$ said they were satisfied, $(18 \%)$ were neither satisfied nor dissatisfied, while $(2 \%)$ were dissatisfied.

\subsection{Overall comment about the system}

Eventually, the last question required the respondents to provide comments on their overall thoughts concerning the WanawakeTujijenge. Below are the main responses received from them:

- The Application is good, easy to use and flexible

- The pages can be translated in Swahili language is [?

- Add SMS feature to send notification whether there is important information

\subsection{Future work}

I have a dream of gender equity community. Working mothers face difficulties on taking care of their babies aged three years and less, some quit jobs some tends to hire girls less than 18 years as domestic workers. A number of domestic violence against babies has been reported, perpetrators being these girls who are supposed to be in schools, unfortunately they are employed as domestic workers. Currently, I 
have planned to build a model day care Centre. To take care of babies aged less than two years to enable working mothers to return to work with peace of mind concerning the wellbeing of their babies, this will also decrease the number of girls aged less than 18 years being employed as domestic workers.

\section{Conclusion}

The proposed ICT solution will often provide necessary information related to gender. Online communication can lead to the empowerment of women, especially to the poor or the marginalized. It will help to understand their strengths, sharpen the way of understanding. The majority of the women with full engagement in politics and get successful in competition in high positions such as president, helps to development advancement and strengthening democracy in general. The big number of women in government leadership is not only advantageous for women themselves, when women are in sufficient numbers in parliaments they also promote children's rights and they tend to speak up more for the interests of communities, because of their close involvement in community life.

\section{References}

[1] International Republican Institute (2016) "Tanzania national elections gender assessment, 1225 eye street nw, suite 700 Washington, dc 20005"(retrieved in January, 2019). pp. 4-7

[2] Powley, E.,( 2007). "Report: Online discussion on women, political participation and decision-making in Africa. United Nations Department of Economic and Social Affairs". [3] Rathgeber, E. M. (2000). "Women, men and ICTs in Africa: Why gender is an issue. Gender and the information revolution in Africa", pp.17-34.

[4] Inter-Parliamentary Union (2015)"Archives of statistical data for respective years [Online].
Available" at: http://www.ipu.org/ wmne/world-arc.. [Accessed 23 February 2019].

[5]National Democratic Institute for International Affairs. (2014). "Women, Technology and Democracy Survey Retrieved from"

https://www.ndi.org/sites/default/files/Women andTechnology\%20-\%20online\%20version.pd f (Accessed 27 December 2018)

[6] Sandys E. (2005) "Gender equality and empowerment of women through ICT: Division for the Advancement of Women Department of Economic and Social Affairs United Nations", pp7-15,

http://www.un.org/womenwatch/daw/public/w 2000-09.05-ict-e.pdf (Retrieved in January, 2019)

[7] Inter-Parliamentary Union ( 2015)"Archives of statistical data for respective years" [Online]. Available at: http://www.ipu.org/ wmn-e/world-arc.. [Accessed 23 February 2019]. 